\title{
A study on relationship between attracting deposits and granting facilities on growth of banks' deposits
}

\author{
Masoud Saeidian $^{\mathrm{a}}$, Seyed Ali Nabavi Chashmi ${ }^{\mathrm{b}}$ and Morteza Valiollahpur $^{\mathrm{c}}$
}

${ }^{a}$ Department of Business Management, Babol Branch, Islamic Azad University, Babol, Iran

${ }^{b}$ Assistant Professor of Department of Business Management, Babol Branch, Islamic Azad University, Babol, Iran

${ }^{c}$ Master of International Commercial Management, Islamic Azad University, Babol, Iran

\section{CHRON I CLE A B T RACT}

\section{Article history: \\ Accepted 10 April 2014 \\ Available online \\ April 182014 \\ Keywords: \\ Attracting deposits \\ Granting facilities \\ Mobilizing resources \\ Bank industry \\ Scoring}

Received December 28, 2013

\begin{abstract}
Banking industry plays essential role for development of macro economy by giving loans to growing business plans and helping economy grow, properly. A bank normally pays a low interest to people who deposit their money into banks and collects interest from people who receive funds. When there is a healthy growth on banks' deposit, banks' managers hope to attract business owners to finance their projects through banks and pay interests. The proposed study of this paper investigates the relationship between lending facility and bank deposits. In addition, the study tries to find out about the possible methods for increasing bank deposits and consequently social investment. Based on the results of our survey, increasing facilities, by assuming all other conditions was remained constant, which increased banks' deposit. In fact, people worked more with banks and branches and conveyed their resources to the banks that granted more deposits. The role of location was so effective to attract deposits so that we must consider the relationship between deposit and the amount of facility payment with location.
\end{abstract}

\section{Introduction}

During the past few years, there have been various studies on investigating banks' business activities (Mester, 1993; Kaparakis et al., 1994; Mitchell \& Onvural, 1996; Demirgüç-Kunt \& Huizinga, 1999). Lin et al. (2014), for instance, analyzed the implication of a bailout package including a loan guarantee and a direct equity capital injection on the equity risk of a distressed bank at the taxpayer expenses. The lending function with a loan guarantee of the bank normally generates the necessity to model equity as a down-and-out call (DOC) option with a capital injection. They provided validation of the DOC model by describing that the values of down-and-out call at different levels of bailout were significant for the distressed bank. In addition, they also explained that a loan guarantee, a

*Corresponding author

E-mail addresses: Anabavichashmi2003@gmail.com (S. A. Nabavi Chashmi) 
capital injection, or a combination of the two tends to be successful in contributing bank equity return. De Graeve et al. (2007) investigated the pass-through from market interest rates to retail bank interest rates by applying a heterogeneous method to the Belgian banking market. They reported that a substantial proportion of the heterogeneity in bank pricing policies could be described by the bank's lending channel and the relative market power hypothesis. They also recommended that the long-term pass-through was typically less than one-for-one, rejecting the completeness hypothesis. While there was no convincing evidence for asymmetry in retail rates, large deviations from equilibrium markups were faster reduced than small deviations.

Godlewski (2014) studied the effect of bank loan announcements on borrower value during the recent boom and bust cycle of the 2000s based on a sample of 253 large loans to French borrowers and reported a significant and negative stock market reaction to bank loan announcements during Financial Crisis. Therefore, although they reported substantial changes in bank behavior during the financial crisis with conservative contractual and organizational modifications, they did not find any support for the certification value of bank loans during a period of increased informational asymmetries.

Hainz et al. (2014) studied the determinants of interest rate spreads of various loan categories in the Czech Republic over the period 2004-2011. They used a detailed bank supervisory dataset, which helps construct the actual spreads for four loan categories, namely small and large corporate loans, consumer loans and mortgages, based on a monthly information. They reported that bank and macroeconomic characteristics matter more for appointing the spreads for small corporate loans and mortgages rather than for large corporate loans and consumer loans.

Claeys and Vander Vennet (2008) studied the determinants of bank interest margins in the Central and Eastern European countries (CEEC) by investigating to what extent the relatively high bank margins in CEEC could be attributed to low efficiency or non-competitive market conditions, controlling for the macroeconomic environment and the effect of foreign and state-owned banks. They systematically compared CEEC banks with Western European banks and reported that banking in the CEEC was on a virtuous path, at least in the EU accession countries.

Sun et al. (2010) examined the differential impacts of monetary policy shock on characteristics of banks' balance sheets; namely deposits, loans, and securities across bank categories such as aggregate banks, state banks, and non-state banks as well as on macroeconomic variables including output, consumer price index, exports, imports, and foreign exchange reserves. They reported the existence of a bank lending channel, an interest rate channel and an asset price channel. In addition, they discussed and explored the distribution and growth impacts of China's monetary policy on China's real economy. Besides, they investigated the impacts of China's monetary policy on China's international trade. They also detected the co-integrating vectors among these variables and set up VEC Models to disclose the long-run relationships that build a relationship among the indicators of monetary policy, bank balance sheet variables and the macroeconomic variables in China.

\section{Problem Statement}

Banking industry plays essential role for development of macro economy by giving loans to growing business plans and helping economy grow, properly. A bank normally pays a low interest to people who deposit their money into banks and collects interest from people who receive funds. When there is a healthy growth on banks' deposit, banks' managers hope to attract business owners to finance their projects through banks and pay interests. However, there are normally various restrictions on the amount of loans assigned to customers. In other words, central banks normally expects banks to maintain a balance between the amount of funds deposited to banks and the amount of loans given to customers. The proposed study of this paper investigates the relationship between lending facility and bank deposits. In addition, the study tries to find out about the possible methods for increasing bank 
deposits and consequently social investment. According to Moosavian (2004), direct deposit, savings deposits as well as investment deposit influences on facilities given to customers shown in Fig. 1.

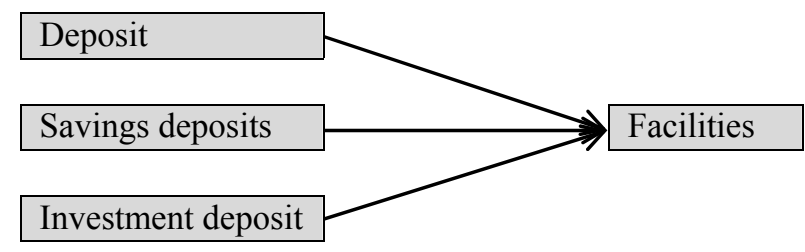

Fig. 1. the relationship between deposits and facility

The thematic scope of this paper is to learn how financing programs absorbs banks' deposits and the study has been accomplished among all active banks in Iran over the period 2012-2013. There are three hypotheses associated with the proposed study of this paper as follows,

1. The location has significant correlation with the amount of deposits.

2. There is a significant relationship between the province location and facility payment.

3 . There is a significant relationship between the amounts of deposits with facility payment.

The society consists of all banks in Iran. The sample consists of a limited number among a statistical society expressing the basic features of the community and it includes all banks and credit institutions under the control of central bank. We gathered the data associated with different bank deposit over the period 2012-2013 and transformed them into a table and defined its growth. In order to achieve good results, we used Analysis of variance (ANOVA) and Analysis of covariance. We used Minitab software to test research hypothesis and we used ITSM to draw time series graphs and study the growth rate.

\section{The results}

In this section, we present details of our findings on testing various hypotheses of the paper. Table 1 demonstrates the summary of some basic statistics. In addition, Fig. 2 shows the growth of deposits in 2012-2013.

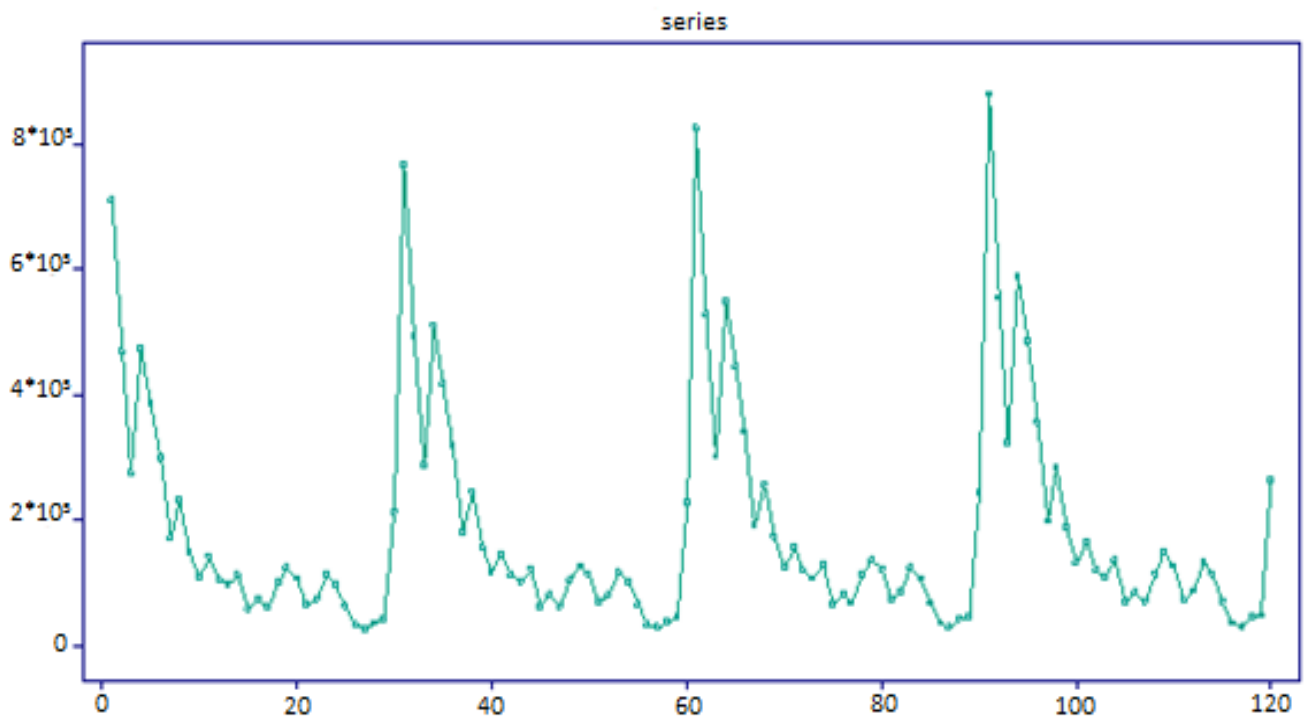

Fig. 2. the growth of deposits in 2012-2013 
Table 1

Percentage of deposits and facility in 2012-2013

\begin{tabular}{|c|c|c|c|c|c|c|c|c|c|c|c|c|}
\hline \multirow[b]{2}{*}{ Province } & \multicolumn{6}{|c|}{ Percent of deposits, 2012} & \multicolumn{6}{|c|}{ Percentage of Facilities, 2012} \\
\hline & Spring & Summer & Autumn & Winter & Mean & Rank & Spring & Summer & Autumn & Winter & Mean & Rank \\
\hline Tehran * & 58.8 & 58.7 & 59.1 & 58.9 & 58.88 & 1 & 56.1 & 56.3 & 56.8 & 57.1 & 56.58 & 1 \\
\hline ESFEHAN & 5.8 & 5.92 & 5.92 & 5.95 & 5.895 & 2 & 4.92 & 4.99 & 5.11 & 5.14 & 5.040 & 2 \\
\hline $\begin{array}{c}\text { Khorasan } \\
\text { Razavi }\end{array}$ & 5.95 & 3.82 & 3.82 & 3.76 & 3.797 & 4 & 3.19 & 3.16 & 3.12 & 3.11 & 3.145 & 4 \\
\hline Mazandaran & 2.25 & 2.21 & 2.17 & 2.2 & 2.208 & 7 & 3.37 & 3.35 & 3.3 & 3.2 & 3.305 & 3 \\
\hline Fars & 3.87 & 3.95 & 3.99 & 3.98 & 3.948 & 3 & 3.11 & 3.09 & 3.06 & 3.07 & 3.083 & 5 \\
\hline Khuzestan & 3.15 & 3.23 & 3.19 & 3.29 & 3.215 & 5 & 2.37 & 2.34 & 2.3 & 2.27 & 2.320 & 7 \\
\hline East Azarbaijan & 2.45 & 2.46 & 2.44 & 2.42 & 2.442 & 6 & 2.66 & 2.63 & 2.66 & 2.66 & 2.652 & 6 \\
\hline Gillan & 1.4 & 1.39 & 1.36 & 1.34 & 1.373 & 10 & 1.99 & 1.95 & 1.9 & 1.86 & 1.925 & 9 \\
\hline Kerman & 1.9 & 1.89 & 1.85 & 1.92 & 1.890 & 8 & 2.1 & 2.09 & 2.09 & 2.11 & 2.097 & 8 \\
\hline $\begin{array}{c}\text { West } \\
\text { Azarbaijan }\end{array}$ & 1.21 & 1.22 & 1.25 & 1.27 & 1.237 & 11 & 1.64 & 1.63 & 1.61 & 1.59 & 1.617 & 10 \\
\hline Kermanshah & 0.89 & 0.9 & 0.9 & 0.9 & 0.897 & 16 & 1.44 & 1.41 & 1.36 & 1.35 & 1.390 & 11 \\
\hline Yazd & 1.16 & 1.14 & 1.12 & 1.12 & 1.135 & 12 & 1.33 & 1.3 & 1.28 & 1.28 & 1.298 & 14 \\
\hline Golestan & 0.86 & 0.86 & 0.86 & 0.82 & 0.850 & 18 & 1.38 & 1.37 & 1.34 & 1.33 & 1.355 & 13 \\
\hline Hamedan & 0.8 & 0.8 & 0.78 & 0.75 & 0.782 & 20 & 0.95 & 0.95 & 0.92 & 0.91 & 0.933 & 19 \\
\hline MARKAZY & 0.93 & 0.95 & 0.93 & 0.92 & 0.933 & 14 & 1.01 & 0.99 & 0.97 & 0.97 & 0.985 & 18 \\
\hline Semnan & 0.48 & 0.48 & 0.48 & 0.48 & 0.480 & 27 & 0.76 & 0.73 & 0.7 & 0.69 & 0.720 & 24 \\
\hline Lorestan & 0.48 & 0.62 & 0.6 & 0.58 & 0.608 & 23 & 1.08 & 1.07 & 1.04 & 1.02 & 1.053 & 16 \\
\hline Ardabil & 0.49 & 0.49 & 0.49 & 0.48 & 0.487 & 26 & 0.81 & 0.81 & 0.79 & 0.78 & 0.798 & 22 \\
\hline Qazvin & 0.83 & 0.81 & 0.8 & 0.79 & 0.808 & 19 & 1.1 & 1.09 & 1.07 & 1.07 & 1.083 & 15 \\
\hline Hormozgan & 1.02 & 0.98 & 0.98 & 1.02 & 1.000 & 13 & 1.07 & 1.05 & 1.01 & 1.01 & 1.035 & 17 \\
\hline Bushehr & 0.89 & 0.9 & 0.88 & 0.87 & 0.885 & 17 & 0.78 & 0.77 & 0.76 & 0.75 & 0.765 & 23 \\
\hline Kurdestan & 0.55 & 0.55 & 0.53 & 0.5 & 0.532 & 24 & 0.68 & 0.68 & 0.67 & 0.66 & 0.673 & 25 \\
\hline Zanjan & 0.62 & 0.62 & 0.61 & 0.60 & 0.613 & 22 & 0.81 & 0.8 & 0.8 & 0.79 & 0.800 & 21 \\
\hline Qum & 0.92 & 0.91 & 0.91 & 0.91 & 0.913 & 15 & 0.86 & 0.87 & 0.85 & 0.85 & 0.858 & 20 \\
\hline Sistan & 0.79 & 0.77 & 0.77 & 0.78 & 0.778 & 21 & 0.63 & 0.62 & 0.61 & 0.6 & 0.615 & 27 \\
\hline Chahar Mahal & 0.52 & 0.50 & 0.49 & 0.49 & 0.500 & 25 & 0.64 & 0.65 & 0.65 & 0.64 & 0.645 & 26 \\
\hline Ilam & 0.27 & 0.26 & 0.26 & 0.25 & 0.260 & 30 & 0.52 & 0.52 & 0.51 & 0.51 & 0.515 & 28 \\
\hline Kohkiloyeh & 0.22 & 0.22 & 0.22 & 0.21 & 0.218 & 31 & 0.41 & 0.4 & 0.39 & 0.39 & 0.398 & 31 \\
\hline North Khorasan & 0.30 & 0.29 & 0.31 & 0.31 & 0.302 & 29 & 0.48 & 0.48 & 0.47 & 0.46 & 0.472 & 29 \\
\hline South Khorasan & 0.36 & 0.35 & 0.34 & 0.34 & 0.348 & 28 & 0.44 & 0.44 & 0.44 & 0.43 & 0.438 & 30 \\
\hline Alborz & 1.74 & 1.76 & 1.74 & 1.79 & 1.758 & 9 & 1.41 & 1.41 & 1.37 & 1.34 & 1.382 & 12 \\
\hline
\end{tabular}

As we can observe from the figure, depository has stationary situation during 2012-2013, and it is apparent from the percentages calculated in Table 1. Table 2 shows Analysis of variance (ANOVA) for the amount of deposit and location of the provinces.

\section{Table 2}

ANOVA for deposits and provinces

\begin{tabular}{cccccc}
\hline & & Explanation & rate & Fisher statistic & Significant \\
\hline $\mathrm{H}_{0}$ & There is no significant relationship between deposits and provinces & \multirow{2}{*}{0.05} & \multirow{2}{*}{10646.84} & 0.000 & Reject the null hypothesis \\
$\mathrm{H}_{1}$ & There is a significant relationship between deposits and provinces & & & & \\
\hline
\end{tabular}

According to the results of Table 2, there are, at least, two observations, which are different from each other. To test the second hypothesis of the number of provinces and the amount of facilities payment, it is necessary that after providing the relevant documents from the Central Bank, we study the relationship between two variables. Based on the results of Table 3, we can observe that there is a significant relationship between the facilities devoted to customers in different provinces. 
Table 3

Analysis of variance for the facility and provinces

\begin{tabular}{|c|c|c|c|c|c|}
\hline \multicolumn{2}{|r|}{ Explanation } & rate & Fisher statistic & Sig. & Conclusions \\
\hline $\mathrm{H}_{0}$ & There is no significant relationship between the facility and the provinces & & & & \\
\hline $\mathrm{H}_{1}$ & There is a significant relationship between the facility and the provinces & 0.05 & 4093.55 & 0.000 & Reject the null hypothesis \\
\hline
\end{tabular}

Finally, Table 4 shows Analysis of Covariance for deposit and the facilities.

\section{Table 4}

Analysis of covariance for deposit and facility

\begin{tabular}{|c|c|c|c|c|c|c|}
\hline \multicolumn{2}{|c|}{ Explanation } & \multirow[b]{2}{*}{ Source of test } & \multirow[b]{2}{*}{ Error rate } & \multirow[b]{2}{*}{ Fisher statistic } & \multirow[b]{2}{*}{ Significant } & \multirow[b]{2}{*}{ Conclusions } \\
\hline H0 & $\mathrm{H} 1$ & & & & & \\
\hline \multirow{2}{*}{$\begin{array}{l}\text { There is no significant relationship } \\
\text { between deposits and facility }\end{array}$} & \multirow{2}{*}{$\begin{array}{l}\text { There is a significant relationship } \\
\text { between deposits and facility }\end{array}$} & Facilities & 0.05 & 65.23 & 0.000 & \multirow{2}{*}{$\begin{array}{l}\text { Reject the null } \\
\text { hypothesis }\end{array}$} \\
\hline & & provinces & 0.05 & 483.04 & 0.000 & \\
\hline
\end{tabular}

According to the results of Table 4, Fisher statistics indicates that the estimated model is quite significant, and there is a significant relationship between the amount of deposits after deduction of legal deposit and facility payment. The role of location is apparent in making this relationship.

\section{Discussion and conclusion}

Based on the results of our survey, increasing facilities, by assuming all other conditions was remained constant, which increased banks' deposit. In fact, people worked more with banks and branches and conveyed their resources to the banks that granted more deposits. The role of location was so effective to attract deposits so that we must consider the relationship between deposit and the amount of facility payment with location. Therefore, it seems there must be a movement towards the implementation of indirect instruments. In addition, there must be some tendencies towards marketoriented financial systems and more focus on allocation of credits methods.

\section{Acknowledgement}

The authors would like to thank the anonymous referees for constructive comments on earlier version of this paper.

\section{References}

Claeys, S., \& Vander Vennet, R. (2008). Determinants of bank interest margins in Central and Eastern Europe: A comparison with the West. Economic Systems, 32(2), 197-216.

De Graeve, F., De Jonghe, O., \& Vennet, R. V. (2007). Competition, transmission and bank pricing policies: Evidence from Belgian loan and deposit markets. Journal of Banking \& Finance, 31(1), 259-278.

Demirgüç-Kunt, A., \& Huizinga, H. (1999). Determinants of commercial bank interest margins and profitability: Some international evidence. The World Bank Economic Review, 13(2), 379-408.

Godlewski, C. J. (2014). Bank loans and borrower value during the global financial crisis: Empirical evidence from France. Journal of International Financial Markets, Institutions and Money, 28, 100-130.

Hainz, C., Horváth, R., \& Hlaváček, M. (2014). The interest rate spreads in the Czech Republic: Different loans, different determinants?. Economic Systems,38(1), 43-54.

Kaparakis, E. I., Miller, S. M., \& Noulas, A. G. (1994). Short-run cost inefficiency of commercial banks: A flexible stochastic frontier approach. Journal of Money, Credit and Banking, 26(4), 875893.

Lin, J. H., Tsai, J. Y., \& Hung, W. M. (2014). Bank equity risk under bailout programs of loan guarantee and/or equity capital injection. International Review of Economics \& Finance, 31, 263274. 
Mester, L. J. (1993). Efficiency in the savings and loan industry. Journal of Banking \& Finance, 17(2), 267-286.

Mitchell, K., \& Onvural, N. M. (1996). Economies of scale and scope at large commercial banks: Evidence from the Fourier flexible functional form. Journal of Money, Credit and Banking, 28(2), 178-199.

Moosavian, S. (2004). Evaluation of Bank Deposits, Islamic Economics Journal, 31-53.

Sun, L., Ford, J.L., \& Dickinson, D.G. (2010). Bank loans and the effects of monetary policy in China: VAR/VECM approach. China Economic Review, 21(1), 65-97. 